\title{
Different approaches for interpretation and reporting of immunohistochemistry analysis results in the bone tissue - a review
}

\author{
Nickolay Fedchenko ${ }^{1,2^{*}}$ and Janin Reifenrath ${ }^{1}$
}

\begin{abstract}
Background: Immunohistochemistry $(\mathrm{IHC})$ is a well-established, widely accepted method in both clinical and experimental parts of medical science. It allows receiving valuable information about any process in any tissue, and especially in bone. Each year the amount of data, received by IHC, grows in geometric progression. But the lack of standardization, especially on the post-analytical stage (interpreting and reporting of results), makes the comparison of the results of different studies impossible.
\end{abstract}

Methods: Comprehensive PubMED literature search with a combination of search words "immunohistochemistry" and "scoring system" was performed and 773 articles describing $\mathrm{IHC}$ results were identified. After further manual analysis 120 articles were selected for detailed evaluation of used approaches.

Results: Six major approaches to the interpretation and presentation of IHC analysis results were identified, analyzed and described.

Conclusions: The overview of the existing approaches in evaluation and interpretation of $\mathrm{HC}$ data, which are provided in the article, can be used in bone tissue research and for either better understanding of existing scoring systems or developing a new one. Standard multiparametric, semiquantitative IHC scoring systems should simplify and clarify the process of interpretation and reporting of received data.

Virtual slides: The virtual slide(s) for this article can be found here: http://www.diagnosticpathology.diagnomx.eu/ vs/13000_2014_221

Keywords: Immunohistochemistry, Score, Grading, Semiquantitative, Bone

\section{Introduction}

The main aim of any histopathological investigation is the identification of a pathological process, therefore special diagnostic features are necessary. Revealing of such features in bone tissue is concerned with several differences compared to other tissues. They start from the very beginning of the long chain of bone specimens obtaining and preparation: bone tissue needs prolonged fixation, often decalcification, special media infiltration and embedding, special equipment for cutting of the tissue specimens (heavy-duty microtomes, diamond circular or wire saws),

\footnotetext{
* Correspondence: fedchenko.nick@gmail.com

'Small Animal Clinic, University of Veterinary Medicine, Foundation,

Bünteweg 9, 30559 Hannover, Germany

${ }^{2}$ Department of Pathological Anatomy and Forensic Medicine, SE

"Dnipropetrovsk Medical Academy of Health Ministry of Ukraine", Dzerginskogo st. 9, 49044 Dnipropetrovsk, Ukraine
}

and even grinding machines for section thinning and grinding $[1,2]$.

Unfortunately there is still no staining procedure invented, which is able to obtain specific information about all desired structures, such as osteoid, mineralized bone matrix, glycosaminoglycans and many others on one slide. To receive important information scientists choose the relevant staining method from a wide range of available ones nowadays. Many excellent reviews presented a variety of staining methods, and their pros and cons [1,3-6]. Among of all methods, immunohistochemistry is a well-established tool, which is widely used to help identifying a wide spectrum of specific pathological processes and which is used in experimental research involving bone tissue. Besides descriptive analyses, multiparametric, semiquantitative scoring systems for evaluating different bone 
parameters represent an universal approach to include histopathologic information in biomedical research [7-9].

In general, one of the most important attribute of any scientific research is its language or nomenclature. The first widely accepted standardization of bone tissue nomenclature was made by Michael Parfitt in 1987 [10]. It was widely accepted and improved markedly the ability of bone researchers to communicate with each other and with nonspecialists, leading to a broader understanding and appreciation of bone research data. After 25 years these recommendations were revised and published in 2012 by David W Dempster and his coauthors [11].

Contrary to the general bone tissue nomenclature, there is still a huge gap in the standardization of IHC methods. IHC is a multistep procedure, and each step is vital. The importance of using standardized rules and environment on each stage of the method is stated in various articles and monographs [12-25]. According to existing conceptions, all variables implying on IHC methods are divided into 3 groups:

1) Pre-analytical variables of IHC tests include Any and all steps in tissue processing, starting from tissue sample obtaining (prolonged ischemia, delayed fixation, etc.), type and length of fixation, decalcification, and elements of tissue handling (proper specimens orientation, careful notation of surgical margins, slicing into sections at 2 to $5 \mathrm{~mm}$ intervals, adequate naming, etc.). Unfortunately, pre-analytical variables cannot be controlled closely, unless you perform all the stages by your own or in certified laboratory [12,15,17,18,21-23].

2) Analytical variables of IHC tests include slide thickness, choosing of antibody clones and their titration, choosing the detection systems and, of course, antigen retrieval (AR) procedure. Current IHC detection systems include peroxisae-anti-peroxidase, the avidin-biotin complex, the biotin-streptavidin amplified systems, tyramine amplification method, immuno-rolling circle amplification, and the polymer enzyme system [26,27]. Antigen retrieval procedures include enzymatic digestion, acid treatment, alkaline hydrolysis, detergent treatment, using the urea solution, refixation with Zn-solution, freeze and thawing, freeze and drying, and of course heating [14,27-29]. AR method should be carefully selected, because many antigens are very sensitive for selected approach, and AR may either enhance the result or completely destroy the target substance of interest [30].

3) Post-analytical variables of IHC tests include interpretation and reporting of the results [31]. Despite all existing recommendations, post-analytical variables are the most frivolous part of many experiments using IHC diagnostics. Misinterpretation of positive and negative results, inappropriate morphological context, unclear scoring systems, and inadequate statistical analysis make it impossible to perceive any data and compare it to other scientific information.

The last step of IHC variables and particularly the scoring systems are the main topic of this review. The fundamental characteristics of a scoring system were suggested by Crissman et al., and included the following: (1) scoring system should be definable, (2) it should be reproducible, and (3) it should produce meaningful results [32]. GibsonCorley et al. also described some key principles for an appropriate scoring system and data evaluation [33]:

- "Masking" of the experimental material to reduce the subjectivity of valued scores;

- a thorough "Examination" of all tissues/slides with creation of a context for scoring tissue lesions;

- specifying "Lesion parameters", which then could be used as score categories;

- using a clear "Scoring definitions" will improve understanding of presented data and increase repeatability of scoring system;

- whenever possible, use "Interpretation Consistency" which imply that all the samples are scored by the same scientist in a reasonable period of time.

Semiquantitative scoring systems are widely used to convert subjective perception of IHC-marker expression by histopathologists into quantitative data, which is then used for statistical analyses and establishing of the conclusions. Without scoring system the description of received data can be provided only with subjective perception, expressed in such adjectives as "strong", "weak", "absent" with modifiers as "more" or "less", like Sojo et al. in evaluation of VEGF and BMP-2, -4 on lengthened rat femurs [34]. Of course, this approach is used by each pathologist while examining the slides, but without conversion into a scoring system - they are just subjective expressions of assessments of solely one pathologist. To reduce subjectivity it is recommended to have at least more than one observer in the study [35].

Most semiquantitative scoring systems usually include multiple parameters which are separately quantified on an ordinal scale and finally combined in a total score. Average scores of the different experimental groups can then be compared by non-parametric statistical tests [7]. The selection of the parameters should be based on the scientific hypothesis or question together with the morphological features of expression of IHC markers which are used in an experiment. The "golden standard" in IHC scoring is defined for the evaluation of only 3 markers so far: Her2/neu, estrogen (ER), and progesterone (PR) for which testing guidelines have been developed [36]. 
For many IHC markers scientists design an individual scoring system, which might be the best possible way to answers the particular scientific question. Lack of standard scoring systems for most IHC markers and particularly for bone tissue leads to the impossibility of the comparison of the results with other studies [37,38].

The present review is aimed to provide the reader with an overview of the existing approaches in evaluation of IHC markers which can be used in bone tissue research and for either better understanding of existing scoring systems or developing a new one.

\section{Review \\ Methods}

Inclusion criteria for comprehensive literature search were a description of IHC results with or without scoring system. The priority was given for the scoring systems for IHC markers that can be used in bone tissue studies. Among such markers were Vascular Endothelial Growth Factor (VEGF), Bone Morphogenic Proteins (BMP), Osteocalcin $(\mathrm{OCN})$, Osteopontin (OPN), and some others with developed scoring systems. Exemplary for VEGF and BMP the tendency in ongoing immunohistochemistry researches is shown in Figure 1 - their number is growing in geometric progression. During last 20 years (from January 1994 to July 2014) the number of articles mentioning VEGF was more than 50000. Bone Morphogenic Protein was mentioned in 9530 articles (Figure 2).

Using a comprehensive PubMED search with a combination of search words "immunohistochemistry" and "scoring system" 773 articles were identified. After further manual analysis 120 articles were selected for detailed evaluation of used approaches for interpretation and reporting of immunohistochemistry analysis results.

\section{Results}

A widely accepted scoring system for immunohistochemistry does not exist yet. The amount of IHC markers used in clinical and experimental research is constantly growing, and so do the amount of researches and data in the field. A closer manual analysis of the selected 120 articles allowed us to identify six major approaches to the interpretation and presentation of received results (Figure 3).

\section{Description of morphological parameters}

This approach is the example of pure qualitative analysis of received information. Verbal description works well if the amount of slides is small and no further statistical analysis of received information is planned; for example, for pilot studies or if IHC analysis is not the main method in an experiment. For presenting the data in the article authors use a literal description of a histological picture (which cells or tissue components were immunopositive) and properties of IHC expression (weak/moderate/strong intensity, staining pattern, background, etc.) [34,39-49]. Detailed examination and description of alkaline phosphatase (ALP), collagen type I (COL I), osteonectin (OTN), OPN, OCN, and bone sialoprotein (BSP) expression in cellular and matrix components of bone was performed by Knabe et al. [49].

Unfortunately, if the results are presented only in a descriptive form, they cannot be compared to other studies directly. However, sometimes such method gives very valuable details, which may be hidden by scoring system categorization $[33,50]$.

\section{Evaluation of number of IHC-positively stained cells and structures}

This is quite simple and commonly used approach in evaluating IHC results. Authors count the absolute quantity of positively stained cells for each investigated IHC

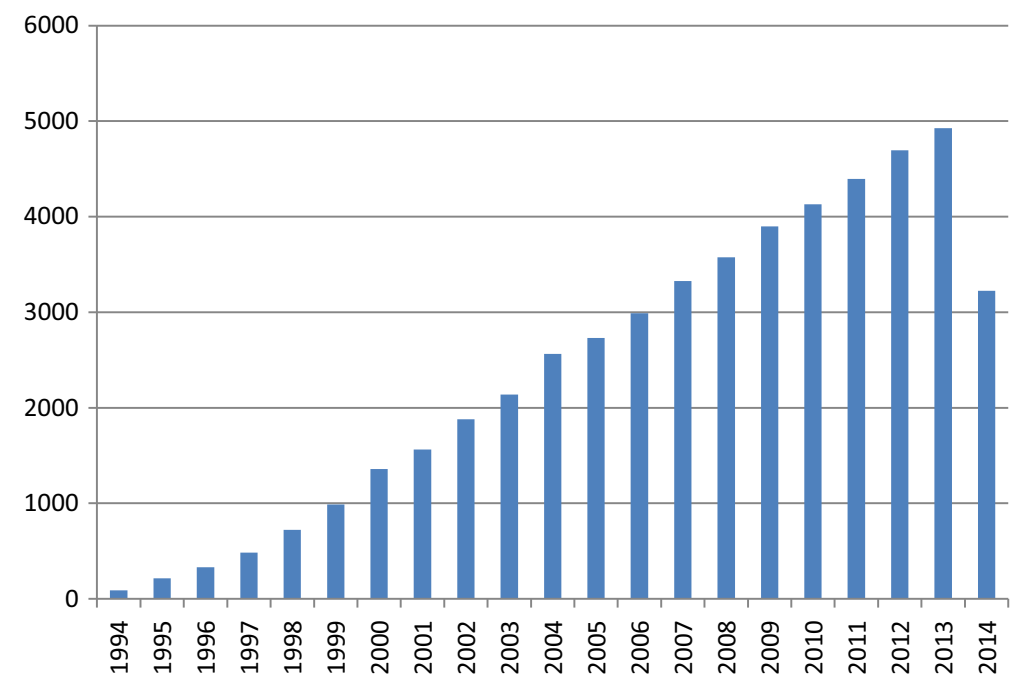

Figure 1 Count of articles, mentioning "VEGF" from 1994 to 2014 according to PubMed. 


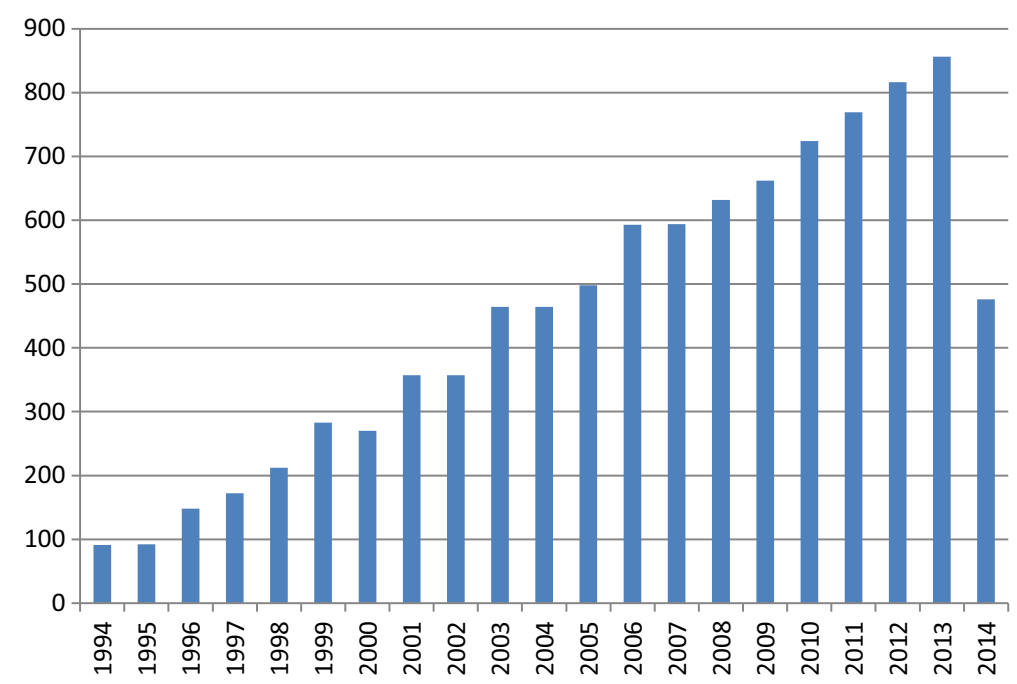

Figure 2 Count of articles, mentioning "Bone Morphogenic Protein" from 1994 to 2014 according to PubMed.

marker in different experimental groups [51-53]. For example, Ishihara et al. counted the number of BMP-2 stained cells in decalcified rabbit nasal bone [52].

IHC markers (factor VIII, CD31, CD34, CD105, VEGF and its receptors, etc.) are often used to establish microvessel density (MVD) [54-64]. This parameter is often presented as a number of microvessels per square millimeter or mean value with standard deviations. For including a microvessel into a count it should be presented as any brown-stained endothelial cell or endothelial-cell cluster that was clearly separate from adjacent microvessels, tumor cells, and other connective-tissue elements [65].

The main problem of cell and structures counting, that it must be very clearly mentioned which cells and/or structures were considered to be "positive". If the IHC staining is not homogeneous, cell populations with different staining properties can be counted separately [66]. Sometimes background staining may lead to misinterpretation [25] and as for the bone tissue, the expression of many IHC markers is observed not only in the cells, but in the osteoid and bone matrix either $[67,68]$.

Results in studies using this method in most cases are presented as mean values of positively stained cells (and/ or structures) among counted experimental groups with their standard deviations [51-64]. If the IHC marker has a high affinity to cells, then the process of positive cells counting may be optimized by some special methods [69].

Evaluation of IHC-positively stained cells and/or area ratio This approach seems to be more time consuming, therefore it is more informative. Researchers count the percentage of positive immunolabeled cells over the total

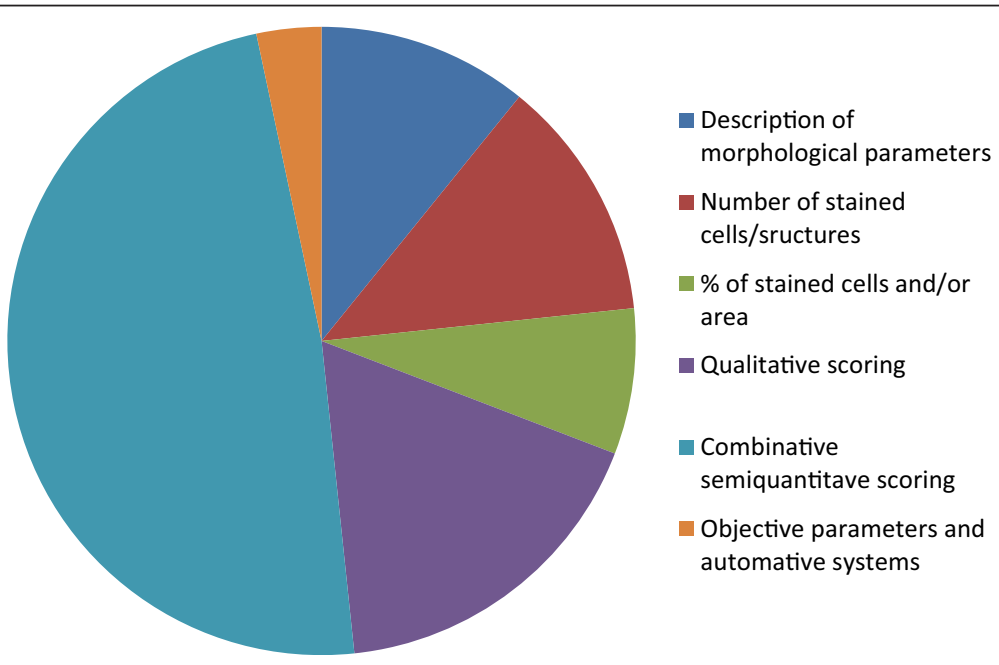

Figure 3 Ratio of different IHC data interpretation and presentation methods in selected articles. 
cells in each selected area [70]. This method can be automated with the use of special plugins for computer counting of general amount of cells and positively stained cells [71].

Because slides are stained separately for each IHC marker (if otherwise is not stated), the \% of positively stained cells is counted separately either. The relation of positively stained cells sometimes is presented in the labeling index (the ratio number of positively stained cells/total number of cells $\times 100)$ [72,73]. Wittenburg et al. evaluated for OCN, OTN, OPN, COL I, CD34, and CD68 the positively stained areas in relation to the total bone surface per section in percentage [2].

As in the second approach, where absolute quantity of cells was calculated, in scoring of \% of immunopositive cells all criteria should be clearly mentioned: which cells and areas were considered to be "positive" or "negative" and why.

The measurement of both, percentage of positively stained cells and area, was performed by Ramazanoglu et al. in the investigation of COL I, BMP-2\4, OCN, and OPN [67]. In this study immunopositive cells were counted in each region of interest (ROI) using a counting grid and their proportion among the total counterstained cell population was analyzed. For COL I stained areas of the ROI were digitally marked and the percentage of stained areas was determined using a computer program.

Usually the combination of quantitative and qualitative parameters leads to expression of received data in a combined scoring systems, which are described later in this article. But the amount of positively stained cells and their relations can be expressed via a simple qualitative scoring system, when certain percentage is given a certain score value [74,75]. Such approach was performed by Sulzbacher et al.: "++" score was given for $50-95 \%$ of positive stained tumor cells; "+" score for 10-49\% of tumor cells positive; "-“ score when less, than $10 \%$ of tumor cells or no visible staining was observed [76]. Semiquantitative scoring with numbers instead of "+" signs can be used either, like did DeRycke et al. in their evaluation of S100A1 expression in ovarian and endometrial endometrioid carcinomas [77]. In this case investigated slides were assigned a score of 0 (no staining), 1 ( $<10 \%$ of neoplastic cells staining), $2(10 \%-$ $50 \%$ of neoplastic cells staining), or 3 ( $>50 \%$ of neoplastic cells staining) $[77,78]$.

Results in studies, measuring the relations of IHCstained cells and areas, are presented as mean values for $\%$ of positively stained cells with their standard deviations $[2,72-75,79,80]$.

\section{Qualitative scoring}

As already described in the first part of this article, qualitative interpretation of IHC data is commonly used among scientists. In addition to the description of the evaluated parameters scientists may use qualitative scoring systems to interpret received data, usually the force of IHC staining in different investigated areas. Score ranks usually lie in a range from "negative" (mostly marked as "-") to "positive", which may be signed with different amount of "+" depending on how many other categories lay between these border parameters [79,81-84]. Most common spectrum of categories, describing different force of IHC expression in investigated groups, include: "negative" $(-)$, "weak" $(+)$, "moderate" $(++)$, "strong" $(+++)$ and their variations [85-91]. If the categories are signed with a numeric value instead of signs, then this approach transforms from qualitative to semi-quantitative $[16,20]$. Osteoprotegerin (OPG), receptor activator of nuclear factor-k ligand (RANKL), ALP, OPN, VEGF, tartrateresistant acid phosphatase (TRAP), COL I, and OCN were assessed using a semi-quantitative ranking that ranged from 0 for no labeling to 4 for intense labeling in the of onlay bone graft remodeling by Hawthrone et al. [92]. Same approach with some extension of scoring groups was used in evaluation of VEGF, BMP-2 and core-binding factor alpha 1 (CBFA1) by Guskuma et al. [93].

Another variant of data presentation is scoring the force of IHC expression among different cell populations and tissue components. An example of this method is demonstrated by $\mathrm{Yu}$ et al. for scoring immunoreactivity for BMPs, BMP antagonists, receptors, and effectors in different cell populations during nonstabilized fracture healing [94]. Similar method was used by $\mathrm{Li}$ et al. for reporting relative abundances of BMP-2 and other IHC markers in uterine structural components and cells $[90,95]$ and by Koerdt et al. in the study of the role of oxidative and nitrosative stress in autogenous bone grafts to the mandible [96].

A more complicated method of assigning different criteria for staining intensity was used by Ding et al., which included assignment of the intensity of staining using a scale of 0-10 (with 0 indicating a lack of brown immunoreactivity and 10 reflecting intense dark brown staining) by three observers. All observers evaluated all slides and observations outside of the 5th to 95th percentile of the remaining observations were considered outlying data and were excluded from analysis. After that the mean was calculated and the results were converted into grades: 1-3 score was assigned “+”, 4-6 was “++", more than 7 was " +++ " [97].

If the results in reports are presented as graded on a scale from " - " to " $+\ldots+$ " they may look more demonstrative, but the range of statistical methods is limited without a conversion to a numeric ordinal score for corresponding staining intensity [98]. However, only two groups, showing "positive" and "negative" expression of IHC marker, may be already compared statistically [99]. 


\section{Combinative semiquantitative scoring}

The most universal way to create a scoring system is to combine all existing approaches into a new one. There are quite a lot of examples of combined multiparameter scoring systems and in this review we will focus on the most recent and widely used ones. In multiparameter scoring systems the semiquantitative approach is used: investigated parameters are valued points from 0 to 4,6 or even 18 depending only on depth of categorization of the used scoring systems. A small number of score categories may reduce the sensitivity of the scoring system, but a large number of ordinal scores may cause difficulty in score assignment as the distinctions between categories become less obvious. This leads to a less repeatability of the scoring system with large number of categories. Some authors suggest that to maximize detection and repeatability of the scoring system, it should contain an average of four to five score levels [100,101].

Simple combinative scoring system for evaluation of OCN and OPN expression was used by Bondarenko et al. [68]. Combination of quantitative and qualitative criteria in the semiquantitative scoring system was used in the study of VEGF-A, VEGF-C and fibroblast growth factor 2 (FGF-2) by Torre et al. [102]. The authors combined cells percentage with a force of IHC-staining and assigned to each field a value from 0 to 4 ( 0 , negative; 1 , $<5 \%$ of the cells with positive staining; 2 , between 5 and $50 \%$ of the cells with positive staining; 3 , more than $50 \%$ of the cells with weak staining and 4 , more than $50 \%$ of the cells with strong staining). The characteristics of selected scoring systems are shown in the Table 1. Similar approach was demonstrated by Jin et al. for evaluation of BMP-2/4, -5 and BMP protein receptor, type IA, but they did not count the intensity of staining [103].

There are a lot of different approaches in establishing the evaluation criteria and corresponding scoring points. They are closely connected to the scientific goal of the experiment and properties of used IHC markers. Most criteria include percentage of positively stained cells and intensity of observed staining [104]. Unfortunately it is not always clear, how authors manipulate with their scoring systems. For example, Megumi et al. scored the percentage of BMP-7-positive stained cells and the intensity of the staining, but it is not clear how the intensity (valued from $1+$ to $3+$ ) implied the percentage (also presented in score values ranging from $1+$ to $3+$ ) [105]. The scoring system is very important in further statistical analysis of received information, because it directly determines the variability of achieved results $[100,106]$ and statistical validity directly depends on the variability of representation [107]. Sometimes authors can perform simple manipulations to extend the range of score values. For example, Klein et al. for VEGF scoring added proportion score values to staining intensity score and received a range of values points from 0 to 6 [108]. Two years later the same author increased the range of points from 6 to 9 by changing arithmetical operation from addition to multiplication (Table 2) [109]. Such manipulation increase the variation row, which gives more statistically reliable results [110].

Three examples of widespread combined scoring systems are Allred-score [96], immunoreactive score (IRS) [111] and H-score [112], which are commonly used for IHC evaluation of progesterone and estrogen receptors. Although these receptors are not expressed in bone tissue, these scoring systems considered to be "gold standard" in IHC-data evaluation and presentation They are widely accepted and recommended by leading associations and organizations [22,36,113,114]. The Allred scoring system combines the percentage of positive cells and the intensity of the reaction product in most of the examined fields. The two scores are added together for a final score with eight possible values. Scores of 0 and 2 are considered negative. Scores of 3 to 8 are considered positive (Table 3) [115,116].

A similar approach to Allred score is demonstrated in so-called "quickscore" system, with the differences in assigned values from 1 to 6 in proportion category A ( $1=$ $0-4 \%, 2=5-19 \%, 3=20-39 \%, 4=40-59 \%, 5=60-79 \%, 6=$ $80-100 \%)$, also multiplication is recommended instead of addition for processing of final score range [117]. In literature Allred score is used for BMP-6 $[118,119]$ and OPN [120] expression evaluation. According to Kejner et al. they used this scoring system for BMP-6 evaluation, but after authors modifications the score range was reduced to 4 categories, which described only intensity of staining: 0 (Low), 1 (Mid-Low), 2 (High-Mid), or 3 (High), which is actually not an Allred score anymore [119].

Table 1 Examples of combinative scoring system for histomorphometry

\begin{tabular}{llll}
\hline Score & Bondarenko et al. for OCN* [68] & Bondarenko et al. for OPN [68] & Torre et al. for VEGF-A, VEGF-C and FGF-2 [102] \\
\hline 0 & - & - & Negative \\
1 & $<25 \%$ & Expression in cells only & $<5 \%$ of the cells with positive staining \\
2 & $25-50 \%$ & Expression in cells and osteoid & Between 5 and $50 \%$ of the cells with positive staining \\
3 & $50-75 \%$ & Focal expression in mature bone & $>50 \%$ of the cells with weak staining \\
4 & $>75 \%$ & Diffuse expression in mature bone & $>50 \%$ of the cells with strong staining \\
\hline
\end{tabular}

*OCN expression was evaluated as a percentage rate of immunopositive peri-implant bone tissue to all peri-implant bone area. 
Table 2 Scoring system used by Klein et al

\begin{tabular}{lll}
\hline $\begin{array}{l}\text { A \% of IHC+ } \\
\text { labeled cells }\end{array}$ & $\begin{array}{l}\text { B intensity of IHC } \\
\text { reaction }\end{array}$ & Final score \\
\hline $0=0 \%$ & $0=$ no reaction & $\begin{array}{l}A+B=\text { range from } 0 \text { to } \\
6[108]\end{array}$ \\
$1=<30 \%$ & $1=$ weak & $A \times B=$ range from 0 to \\
$2=30-60 \%$ & $2=$ mild & $9[109]$ \\
$3=>60 \%$ & $3=$ strong & \\
\hline
\end{tabular}

The $\mathrm{H}$-score is determined by adding the results of multiplication of the percentage of cells with staining intensity ordinal value (scored from 0 for "no signal" to 3 for "strong signal") with 300 possible values. In this system, $<1 \%$ positive cells is considered to be a negative result $[112,121]$. According to Dabbs et al., H-score has a broader dynamic range compared to Allred score [9].

The immunoreactive score (IRS) gives a range of $0-12$ as a product of multiplication between positive cells proportion score (0-4) and staining intensity score $(0-3)$ (Table 4) [111]. IRS was used for expression of wide spectrum of IHC markers (BMP and its receptors, VEGF, vWF and others) in bone studies by Koerdt et al. $[122,123]$. For evaluation of BMP-6 reaction the IRS score with some modifications was used by Raida et al., but in the example used by authors the calculation of IRS is performed by summarizing of different score values [124]. Even more controversial approach in calculation of IRS score we can observe in the evaluation of BMP-2 score by de Carvalho et al., where authors mentioned, that they scored percentage of positive cells, but there were only two categories of stain intensity: score 1 (absent or weak expression) and score 2 (strong expression); and it is unclear what further manipulations authors performed with the score values - addition or multiplication [125].

If the examined sample stains for IHC marker heterogeneously, then each intensity of staining is scored independently and the results are summed. The example of such approach is given by Kraewska et al.: when a specimen contained $50 \%$ of the tumor cells with moderate intensity $(2 \times 2=4), 25 \%$ of tumor cells with intense immunostaining $(1 \times 3=3)$, and $25 \%$ of cells with weak intensity $(1 \times 1=1)$, the score was $4+3+1=8$ [126].

Table 3 Allred scoring system

\begin{tabular}{llll}
\hline Proportion score A & Positive cells, \% & Intensity & Intensity score B \\
\hline 0 & 0 & None & 0 \\
1 & $<1$ & Weak & 1 \\
2 & 1 to 10 & Intermediate & 2 \\
3 & 11 to 33 & Strong & 3 \\
4 & 34 to 66 & Final score range (A + B): 0-8 \\
5 & $\geq 67$ & \\
\hline
\end{tabular}

Table 4 The immunoreactive score (IRS)

\begin{tabular}{lll}
\hline $\begin{array}{l}\text { A (percentage of } \\
\text { positive cells) }\end{array}$ & $\begin{array}{l}\text { B (intensity of } \\
\text { staining) }\end{array}$ & $\begin{array}{l}\text { IRS score (multiplication } \\
\text { of } \mathbf{A} \text { and } \mathbf{B} \text { ) }\end{array}$ \\
\hline $0=$ no positive cells & $\begin{array}{l}0=\text { no color } \\
\text { reaction }\end{array}$ & $0-1=$ negative \\
$\begin{array}{l}1=<10 \% \text { of positive } \\
\text { cells }\end{array}$ & $1=$ mild reaction & $2-3=$ mild \\
$2=10-50 \%$ positive cells & $\begin{array}{l}2=\text { moderate } \\
\text { reaction }\end{array}$ & $4-8=$ moderate \\
$3=51-80 \%$ positive cells & $\begin{array}{l}3=\text { intense } \\
\text { reaction }\end{array}$ & $9-12=$ strongly positive \\
$4=>80 \%$ positive cells & Final IRS score $(\mathbf{A} \times \mathbf{B}): \mathbf{0}-\mathbf{1 2}$
\end{tabular}

Allred score, "quickscore", H-score, and IRS are aimed only to the cellular staining evaluation and without modifications cannot be used for expression of extracellular staining.

\section{Evaluation of objective parameters and automated approaches for calculation and scoring}

Calculation of objective parameters such as optical density of positively IHC stained areas is a very perspective field, because until today the most common approach for analysis and interpretation of the IHC staining is a timeconsuming and subjective manual procedure [71]. Due to broad scoring categories, nonstandardized approaches, subjectivity and variability of purely visual inspection the method of manual scoring IHC slides is less than precise [127]. In this review we briefly discuss major aspects of evaluating and scoring of some IHC parameters, which can be used in bone tissue research. One of the parameters that can be obtained and measured after IHC of bone tissue is Integrated Optical Density (IOD). This parameter was evaluated by Dehao et al. for VEGF expression [128] and by other authors for different IHC markers $[129,130]$. Results in experiments, measuring objective parameters, are presented in mean values of calculated parameter with their standard deviations. Of course, measuring objective parameters significantly reduces amount of subjective judgment which may implement the results. But high consumption of observer's time makes it almost impossible to use any manual scoring in a large screening application. In such cases using personal computers with special analytical software may be the only alternative. The automation has penetrated in almost all fields of IHC [131,132], but interpretation and analysis of results remain an unreached milestone. Some products for automated measure are already present on the market and used in different experiments [71,127,133-136]. Kraan et al. compared manual and automated measurements of IOD and number of immunopositive cells in their work [137].

Rizzardi et al. compared pathologists manual scoring system with digital image analysis systems using digital 
data based on IHC-positive area (\%Pos) and data combining area and staining intensity (OD $\times \%$ Pos) [78].

Unfortunately, available automated systems are too far from ideal: some programs are not able to isolate individual cells, but most are still not capable for interpretation of morphological features [127]. Another major disadvantage of such systems are the costs and special skills required for the introduction and maintenance of all system components (software, hardware) [137]. On the other hand, manual scoring is not suitable for a large massive of data analysis [138], and in the authors opinion, the improvement of automated image analysis systems is just a question of time.

\section{Conclusions}

Summarized, the six listed approaches for evaluation, interpretation, and presentation of received experimental IHC information contain significantly different data. Which approach is chosen depends only on the researcher's opinion. Selection of an existing or developing of a new scoring system should be performed as early as possible, probably on such stages as developing the experimental design, purposes formationing and choosing tissue sampling parameters.

This review gives an overview on currently available approaches for evaluating and presenting data of bone immunohistochemistry, which may also be used in any other IHC field. In the authors opinion, a good scoring system is one of the key factors for any experiment. It helps to connect a specific scientific question with a clear presentation of achieved results. Properly selected or even newly developed scoring system will significantly increase the scientists productivity, save time and money.

Individual scoring systems for particular IHC marker may be the best possible way to answer the special scientific question, but lack of standard scoring systems for most IHC markers, and particularly for bone tissue, leads to the impossibility of the comparison of the results with other studies. Developing of standard multiparametric, semiquantitative IHC scoring systems for bone tissue studies should simplify and clarify the process of interpretation and reporting of received data.

This review hopefully fulfills the main purpose to present existing approaches to interpretation and presentation of IHC scoring methods and offers researchers assistance with the critical selection and application of scores or appropriate modifications for the individual scientific question. Maybe future investigations even develop new "gold standards" for additional IHC parameters, which would achieve a better comparability between different study results.

\footnotetext{
Abbreviations

ALP: Alkaline phosphatase; AR: Antigen retrieval; BMP: Bone morphogenic protein; COL I: Collagen type I; FGF: Fibroblast growth factor; IHC: Immunohistochemistry; IOD: Integrated optical density; IRS: Immunoreactive score; MC: Manual cell counting; MVD: Microvessel
}

density; OCN: Osteocalcin; OD: Optical density; OMP: Objective measurable parameters; OPN: Osteopontoin; OPG: Osteoprotegerin; OTN: Osteonectin; PCNA: Proliferating cell nuclear antigen; ROI: Region of interest; VEGF: Vascular endothelial growth factor; vWF: Von Willebrand factor.

\section{Competing interests}

The authors declare that they have no competing interests.

\section{Authors' contributions}

NF formed the study design, carried out the literature search, analyzed and interpreted all data, and drafted the manuscript. JR made substantial contributions to conception and design, and revised it critically for important intellectual content. All authors read and approved the final manuscript.

\section{Acknowledgements}

This work was provided within the collaborative research center 599 'Sustainable bioresorbable and permanent implants of metallic and ceramic materials', subproject R6, which was funded by the German Research Foundation (DFG). Thanks to Franziska Foth for her helpful comments.

Received: 17 September 2014 Accepted: 10 November 2014 Published online: 29 November 2014

\section{References}

1. An YH, Martin KL: Handbook of Histology Methods for Bone and Cartilage. Softcover reprint of hardcover 1st ed. 2003 edition. Totowa, NJ: Humana Press; 2010.

2. Wittenburg G, Volkel C, Mai R, Lauer G: Immunohistochemical comparison of differentiation markers on paraffin and plastic embedded human bone samples. J Physiol Pharmacol Off J Pol Physiol Soc 2009, 60(Suppl 8):43-49.

3. Bancroft JD, Gamble M: Theory and Practice of Histological Techniques, $6 e$. 6th edition. Edinburgh: Churchill Livingstone; 2007.

4. Dettmeyer R: Forensic Histopathology: Fundamentals and Perspectives. 1st ed. 2011. Corr. 5th printing 2013 edition. Berlin: Springer; 2011.

5. Mills SE: Histology for Pathologists. 4th edition. Philadelphia: LWW; 2012

6. Recker RR, Kimmel DB, Dempster D, Weinstein RS, Wronski TJ, Burr DB: Issues in modern bone histomorphometry. Bone 2011, 49:955-964.

7. Klopfleisch R: Multiparametric and semiquantitative scoring systems for the evaluation of mouse model histopathology-a systematic review. BMC Vet Res 2013, 9:123.

8. Jambhekar N, Chaturvedi A, Madur B: Immunohistochemistry in surgical pathology practice: a current perspective of a simple, powerful, yet complex, tool. Indian J Pathol Microbiol 2008, 51:2.

9. Dabbs DJ: Diagnostic Immunohistochemistry. Elsevier Health Sciences; 2013. ISBN 978-1-4160-5766-6.

10. Parfitt AM, Drezner MK, Glorieux FH, Kanis JA, Malluche H, Meunier PJ, Ott SM, Recker RR: Bone histomorphometry: standardization of nomenclature, symbols, and units. report of the ASBMR Histomorphometry Nomenclature Committee. J Bone Miner Res Off J Am Soc Bone Miner Res 1987, 2:595-610.

11. Dempster DW, Compston JE, Drezner MK, Glorieux FH, Kanis JA, Malluche H, Meunier PJ, Ott SM, Recker RR, Parfitt AM: Standardized nomenclature, symbols, and units for bone histomorphometry: a 2012 update of the report of the ASBMR Histomorphometry Nomenclature Committee. J Bone Miner Res Off J Am Soc Bone Miner Res 2013, 28:2-17.

12. Shi S-R, Liu C, Taylor CR: Standardization of immunohistochemistry for formalin-fixed, paraffin-embedded tissue sections based on the antigen-retrieval technique: from experiments to hypothesis. $J$ Histochem Cytochem 2007, 55:105-109.

13. Dunstan RW, Wharton KA, Quigley C, Lowe A: The use of immunohistochemistry for biomarker assessment-can it compete with other technologies? Toxicol Pathol 2011, 39:988-1002.

14. Shi $S-R$, Shi $Y$, Taylor CR: Antigen retrieval immunohistochemistry review and future prospects in research and diagnosis over two decades. J Histochem Cytochem 2011, 59:13-32.

15. Kaczorowski S, Kaczorowska M: Is standardization possible in immunohistochemical examination? Patol Pol 1992, 43:10-15.

16. Walker RA: Quantification of immunohistochemistry-issues concerning methods, utility and semiquantitative assessment I. Histopathology 2006 , 49:406-410.

17. Fritz $P$, Hönes J, Lutz D, Multhaupt $H$, Mischlinski A, Dörrer $A$, Schwarzmann P, Tuczek HV, Müller W: Quantitative immunohistochemistry: 
standardization and possible application in research and surgical pathology. Acta Histochem Supp/ 1989, 37:213-219.

18. Taylor CR: An exaltation of experts: concerted efforts in the standardization of immunohistochemistry. Hum Pathol 1994, 25:2-11.

19. Seidal T, Balaton AJ, Battifora H: Interpretation and quantification of immunostains. Am J Surg Pathol 2001, 25:1204-1207.

20. Taylor CR, Levenson RM: Quantification of immunohistochemistry-issues concerning methods, utility and semiquantitative assessment II. Histopathology 2006, 49:411-424.

21. O'Leary TJ: Standardization in immunohistochemistry. App/ Immunohistochem Mol Morphol AlMM Off Publ Soc Appl Immunohistochem 2001, 9:3-8.

22. Canadian Association of Pathologists-Association canadienne des pathologistes National Standards Committee, Torlakovic EE, Riddell R, Banerjee D, El-Zimaity H, Pilavdzic D, Dawe P, Magliocco A, Barnes P, Berendt R, Cook D, Gilks B, Williams G, Perez-Ordonez B, Wehrli B, Swanson PE, Otis CN, Nielsen S, Vyberg M, Butany J: Canadian Association of Pathologists-Association canadienne des pathologistes National Standards Committee/Immunohistochemistry: best practice recommendations for standardization of immunohistochemistry tests. Am J Clin Pathol 2010, 133:354-365.

23. Goldstein NS, Hewitt SM, Taylor CR, Yaziji H, Hicks DG, Members of Ad-Hoc Committee On Immunohistochemistry Standardization: Recommendations for improved standardization of immunohistochemistry. Appl Immunohistochem Mol Morphol AIMM Off Publ Soc Appl Immunohistochem 2007, 15:124-133.

24. Lin F, Prichard J: Handbook of Practical Immunohistochemistry: Frequently Asked Questions. 2011th edition. New York: Springer; 2011

25. Van Diest PJ, van Dam P, Henzen-Logmans SC, Berns E, van der Burg ME, Green J, Vergote I: A scoring system for immunohistochemical staining: consensus report of the task force for basic research of the EORTC-GCCG. European Organization for Research and Treatment of Cancer-Gynaecological Cancer Cooperative Group. J Clin Pathol 1997, 50:801-804.

26. Ramos-Vara JA: Technical aspects of immunohistochemistry. Vet Pathol Online 2005, 42:405-426.

27. Warford A, Akbar H, Riberio D: Antigen retrieval, blocking, detection and visualisation systems in immunohistochemistry: a review and practical evaluation of tyramide and rolling circle amplification systems. Methods San Diego Calif 2014, http://dx.doi.org/10.1016/j.ymeth.2014.03.001.

28. Shi S-R, Cote RJ, Taylor CR: Antigen retrieval immunohistochemistry: past present, and future. J Histochem Cytochem 1997, 45:327-343.

29. Taylor CR: Immunohistochemistry in surgical pathology: principles and practice. Methods Mol Biol Clifton NJ 2014, 1180:81-109.

30. Yamashita S: Heat-induced antigen retrieval: mechanisms and application to histochemistry. Prog Histochem Cytochem 2007, 41:141-200.

31. Chu P, Weiss L: Modern Immunohistochemistry with DVD-ROM. Cambridge University Press; 2014. ISBN 9781107040151.

32. Crissman JW, Goodman DG, Hildebrandt PK, Maronpot RR, Prater DA, Riley $\mathrm{JH}$, Seaman WJ, Thake DC: Best practices guideline: toxicologic histopathology. Toxicol Pathol 2004, 32:126-131.

33. Gibson-Corley KN, Olivier AK, Meyerholz DK: Principles for valid histopathologic scoring in research. Vet Pathol 2013, 50:1007-1015.

34. Sojo K, Sawaki Y, Hattori H, Mizutani H, Ueda M: Immunohistochemical study of vascular endothelial growth factor (VEGF) and bone morphogenetic protein-2, -4 (BMP-2, -4) on lengthened rat femurs. J Cranio-Maxillo-fac Surg Off Publ Eur Assoc Cranio-Maxillo-fac Surg 2005, 33:238-245.

35. Obuchowski NA: How many observers are needed in clinical studies of medical imaging? Am J Roentgenol 2004, 182:867-869.

36. Fitzgibbons PL, Dillon DA, Alsabeh R, Berman MA, Hayes DF, Hicks DG, Hughes KS, Nofech-Mozes S: Template for reporting results of biomarker testing of specimens from patients with carcinoma of the breast. Arch Pathol Lab Med 2014, 138:595-601.

37. Adams EJ, Green JA, Clark AH, Youngson JH: Comparison of different scoring systems for immunohistochemical staining. J Clin Pathol 1999, 52:75-77.

38. Rhodes A, Jasani B, Balaton AJ, Miller KD: Immunohistochemical demonstration of oestrogen and progesterone receptors: correlation of standards achieved on in house tumours with that achieved on external quality assessment material in over 150 laboratories from 26 countries. J Clin Pathol 2000, 53:292-301.

39. Campisi P, Hamdy RC, Lauzier D, Amako M, Rauch F, Lessard M-L: Expression of bone morphogenetic proteins during mandibular distraction osteogenesis. Plast Reconstr Surg 2003, 111:201-208. discussion 209-210.
40. Yazawa M, Kishi K, Nakajima H, Nakajima T: Expression of bone morphogenetic proteins during mandibular distraction osteogenesis in rabbits. J Oral Maxillofac Surg Off J Am Assoc Oral Maxillofac Surg 2003, 61:587-592.

41. Long GV, Wilmott JS, Capper D, Preusser M, Zhang YE, Thompson JF, Kefford RF, von Deimling A, Scolyer RA: Immunohistochemistry is highly sensitive and specific for the detection of V600E BRAF mutation in melanoma. Am J Surg Pathol 2013, 37:61-65.

42. Hussein KA, Choksi K, Akeel S, Ahmad S, Megyerdi S, El-Sherbiny M, Nawaz M, Abu El-Asrar A, Al-Shabrawey M: Bone morphogenetic protein 2: a potential new player in the pathogenesis of diabetic retinopathy. Exp Eye Res 2014, 125:79-88.

43. Campisi P, Hamdy RC, Lauzier D, Amako M, Schloss MD, Lessard ML: Overview of the radiology, histology, and bone morphogenetic protein expression during distraction osteogenesis of the mandible. J Otolaryngol 2002, 31:281-286.

44. Cao L, Wang J, Hou J, Xing W, Liu C: Vascularization and bone regeneration in a critical sized defect using 2-N,6-O-sulfated chitosan nanoparticles incorporating BMP-2. Biomaterials 2014, 35:684-698.

45. Adeyemo WL, Reuther T, Bloch W, Korkmaz Y, Fischer JH, Zöller JE, Kuebler AC: Influence of host periosteum and recipient bed perforation on the healing of onlay mandibular bone graft: an experimental pilot study in the sheep. Oral Maxillofac Surg 2008, 12:19-28.

46. Alberius P, Gordh M: Osteopontin and bone sialoprotein distribution at the bone graft recipient site. Arch Otolaryngol Head Neck Surg 1998, 124:1382-1386

47. Zhu W-Q, Wang X, Wang X-X, Wang Z-Y: Temporal and spatial expression of osteoprotegerin and receptor activator of nuclear factor -kappaB ligand during mandibular distraction in rats. J Cranio-Maxillo-fac Surg Off Publ Eur Assoc Cranio-Maxillo-fac Surg 2007, 35:103-111.

48. Tanaka $H$, Mine $T$, Ogasa $H$, Taguchi $T$, Liang CT: Expression of RANKL/OPG during bone remodeling in vivo. Biochem Biophys Res Commun 2011, 411:690-694.

49. Knabe C, Kraska B, Koch C, Gross U, Zreiqat H, Stiller M: A method for immunohistochemical detection of osteogenic markers in undecalcified bone sections. Biotech Histochem 2006, 81:31-39.

50. Cross SS: Grading and scoring in histopathology. Histopathology 1998, 33:99-106.

51. Yan Y, Gong P, Jin W, Xu J, Wu X, Xu T, Hang Q, Fu H, Kei K, Gao Y: The cell-specific upregulation of bone morphogenetic protein-10 (BMP-10) in a model of rat cortical brain injury. J Mol Histol 2012, 43:543-552.

52. Ishihara Y, Ueki K, Sotobori M, Marukawa K, Moroi A: Bone regeneration by statin and low-intensity pulsed ultrasound (LIPUS) in rabbit nasal bone. J Cranio-Maxillo-fac Surg Off Publ Eur Assoc Cranio-Maxillo-fac Surg 2014, 42:185-193.

53. Shi W, Gong P, Fan J, Yan YH, Ni L, Wu X, Cui G, Wu X, Gu X, Chen J: The expression pattern of ADP-ribosyltransferase 3 in rat traumatic brain injury. J Mol Histol 2012, 43:37-47.

54. Anannamcharoen S, Nimmanon T: Study of the vascular endothelial growth factor (VEGF) expression and microvascular density (MVD) in primary colorectal cancer specimens. J Med Assoc Thail Chotmaihet Thangphaet 2012, 95:1041-1047.

55. Kumagai Y, Sobajima J, Higashi M, Ishiguro T, Fukuchi M, Ishibashi K, Baba H, Mochiki E, Yakabi K, Kawano T, Tamaru J, Ishida H: Angiogenesis in superficial esophageal squamous cell carcinoma: assessment of microvessel density based on immunostaining for CD34 and CD105. Jpn J Clin Oncol 2014, 44:526-533.

56. Łuczyńska E, Gasińska A, Wilk W: Microvessel density and expression of vascular endothelial growth factor in clinically localized prostate cancer. Pol J Pathol Off J Pol Soc Pathol 2013, 64:33-38.

57. Elezoğlu B, Tolunay S: The relationship between the stromal mast cell number, microvessel density, c-erbB-2 staining and survival and prognostic factors in colorectal carcinoma. Türk Patoloji Derg 2012, 28:110-118.

58. Wobser M, Siedel C, Kneitz H, Bröcker E-B, Goebeler M, Houben R, Geissinger $\mathrm{E}$ : Microvessel density and expression of vascular endothelial growth factor and its receptors in different subtypes of primary cutaneous B-cell lymphoma. Acta Derm Venereol 2013, 93:656-662.

59. Wang $\mathrm{H}-\mathrm{L}$, Zhang Z-L: Analysis of the relationship between ultrasound of breast cancer DOT-SDI and the expression of MVD, VEGF and HIF-1a. Cell Biochem Biophys 2014, 70(1):205-208.

60. Bădescu A, Georgescu CV, Vere CC, Crăițoiu S, Grigore D: Correlations between Her2 oncoprotein, VEGF expression, MVD and 
clinicopathological parameters in gastric cancer. Romanian J Morphol Embryol Rev Roum Morphol Embryol 2012, 53:997-1005.

61. Cai $Y$, Zhang J: Expression of fascin and correlation with MVD in sinonasal inverted papilloma. Lin Chuang Er Bi Yan Hou Tou Jing Wai Ke Za Zhi J Clin Otorhinolaryngol Head Neck Surg 2012, 26:629-632.

62. Bodnar M, Szylberg $Ł$, Kaźmierczak W, Marszałek A: Evaluation of microvessel density (MVD) in laryngeal squamous cell carcinoma. Przeglad Lek 2012, 69:726-730.

63. Boëck-Neto RJ, Artese L, Piattelli A, Shibli JA, Perrotti V, Piccirilli M, Marcantonio E: VEGF and MVD expression in sinus augmentation with autologous bone and several graft materials. Oral Dis 2009, 15:148-154.

64. Geiger F, Beverungen M, Lorenz H, Wieland J, Fehr M, Kasten P: Bone substitute effect on vascularization and bone remodeling after application of phVEGF165 transfected BMSC. J Funct Biomater 2012, 3:313-326.

65. Weidner N, Semple JP, Welch WR, Folkman J: Tumor angiogenesis and metastasis - correlation in invasive breast carcinoma. N Engl J Med 1991, 324:1-8.

66. Chen J, Wu X, Shao B, Zhao W, Shi W, Zhang S, Ni L, Shen A: Increased expression of TNF receptor-associated factor 6 after rat traumatic brain injury. Cell Mol Neurobiol 2011, 31:269-275.

67. Ramazanoglu M, Lutz R, Rusche P, Trabzon L, Kose GT, Prechtl C, Schlegel KA: Bone response to biomimetic implants delivering BMP-2 and VEGF: an immunohistochemical study. J Cranio-Maxillofac Surg 2013, 41:826-835.

68. Bondarenko A, Angrisani N, Meyer-Lindenberg A, Seitz JM, Waizy H, Reifenrath J: Magnesium-based bone implants: immunohistochemical analysis of peri-implant osteogenesis by evaluation of osteopontin and osteocalcin expression. J Biomed Mater Res A 2014, 102:1449-1457.

69. Bologna-Molina R, Damián-Matsumura P, Molina-Frechero N: An easy cell counting method for immunohistochemistry that does not use an image analysis program. Histopathology 2011, 59:801-803.

70. Wang C-J, Huang K-E, Sun Y-C, Yang Y-J, Ko J-Y, Weng L-H, Wang F-S: VEGF modulates angiogenesis and osteogenesis in shockwave-promoted fracture healing in rabbits. J Surg Res 2011, 171:114-119.

71. Varghese F, Bukhari AB, Malhotra R, De A: IHC Profiler: an open source plugin for the quantitative evaluation and automated scoring of immunohistochemistry images of human tissue samples. PLoS One 2014, 9:e96801.

72. Wehrhan F, Amann K, Molenberg A, Lutz R, Neukam FW, Schlegel KA: Critical size defect regeneration using PEG-mediated BMP-2 gene delivery and the use of cell occlusive barrier membranes - the osteopromotive principle revisited. Clin Oral Implants Res 2013, 24:910-920.

73. Wehrhan F, Amann K, Molenberg A, Lutz R, Neukam FW, Schlegel KA: PEG matrix enables cell-mediated local BMP-2 gene delivery and increased bone formation in a porcine critical size defect model of craniofacial bone regeneration. Clin Oral Implants Res 2012, 23:805-813.

74. Yoshikawa H, Rettig WJ, Takaoka K, Alderman E, Rup B, Rosen V, Wozney JM, Lane JM, Huvos AG, Garin-Chesa P: Expression of bone morphogenetic proteins in human osteosarcoma. immunohistochemical detection with monoclonal antibody. Cancer 1994, 73:85-91.

75. Cheung LK, Zheng LW, Ma L: Effect of distraction rates on expression of bone morphogenetic proteins in rabbit mandibular distraction osteogenesis. J Cranio-Maxillo-fac Surg Off Publ Eur Assoc Cranio-Maxillo-fac Surg 2006, 34:263-269.

76. Sulzbacher I, Birner P, Trieb K, Pichlbauer E, Lang S: The expression of bone morphogenetic proteins in osteosarcoma and its relevance as a prognostic parameter. J Clin Pathol 2002, 55:381-385.

77. DeRycke MS, Andersen JD, Harrington KM, Pambuccian SE, Kalloger SE, Boylan KLM, Argenta PA, Skubitz APN: S100A1 expression in ovarian and endometrial endometrioid carcinomas is a prognostic indicator of relapse-free survival. Am J Clin Pathol 2009, 132:846-856.

78. Rizzardi AE, Johnson AT, Vogel RI, Pambuccian SE, Henriksen J, Skubitz AP, Metzger GJ, Schmechel SC: Quantitative comparison of immunohistochemical staining measured by digital image analysis versus pathologist visual scoring. Diagn Pathol 2012, 7:42.

79. Soares AF, Xavier RL de F, da Costa Miguel MC, de Souza LB, Pinto LP: Bone morphogenetic protein-2/4 and bone morphogenetic protein receptor type IA expression in metastatic and nonmetastatic oral squamous cell carcinoma. Am J Otolaryngol 2010, 31:266-271.
80. Laboux O, Ste-Marie L-G, Glorieux FH, Nanci A: Quantitative immunogold labeling of bone sialoprotein and osteopontin in methylmethacrylateembedded rat bone. J Histochem Cytochem Off J Histochem Soc 2003, 51:61-67.

81. Ida CM, Vrana JA, Rodriguez FJ, Jentoft ME, Caron AA, Jenkins SM, Giannini C: Immunohistochemistry is highly sensitive and specific for detection of BRAF V600E mutation in pleomorphic xanthoastrocytoma. Acta Neuropathol Commun 2013, 1:20.

82. Sand JP, Kokorina NA, Zakharkin SO, Lewis JS, Nussenbaum B: BMP-2 expression correlates with local failure in head and neck squamous cell carcinoma. Otolaryngol-Head Neck Surg Off J Am Acad Otolaryngol-Head Neck Surg 2014, 150:245-250.

83. De Oliveira Neto PJ, Cricchio G, Hawthorne AC, Okamoto R, Sennerby L, Lungren S, Salata LA: Tomographic, histological, and immunohistochemical evidences on the use of N-butyl-2-cyanoacrilate for onlay graft fixation in rabbits. Clin Implant Dent Relat Res 2012, 14:861-871.

84. Yang R, Davies CM, Archer CW, Richards RG: Immunohistochemistry of matrix markers in Technovit 9100 New-embedded undecalcified bone sections. Eur Cell Mater 2003, 6:57-71. discussion 71.

85. Zimmermann A-K, Camenisch U, Rechsteiner MP, Bode-Lesniewska B, Rössle M: Value of immunohistochemistry in the detection of BRAFV600E mutations in fine-needle aspiration biopsies of papillary thyroid carcinoma. Cancer Cytopathol 2014, 122:48-58.

86. Kapoor P, Deshmukh R: VEGF: a critical driver for angiogenesis and subsequent tumor growth: An IHC study. J Oral Maxillofac Pathol JOMFP 2012, 16:330-337.

87. Kukreja I, Kapoor P, Deshmukh R, Kulkarni V: VEGF and CD 34: a correlation between tumor angiogenesis and microvessel density-an immunohistochemical study. J Oral Maxillofac Pathol JOMFP 2013, $17: 367-373$

88. Bösmüller H, Fischer A, Pham DL, Fehm T, Capper D, von Deimling A, Bonzheim I, Staebler A, Fend F: Detection of the BRAF V600E mutation in serous ovarian tumors: a comparative analysis of immunohistochemistry with a mutation-specific monoclonal antibody and allele-specific PCR. Hum Pathol 2013, 44:329-335.

89. Raica M, Cimpean AM, Anghel A: Immunohistochemical expression of vascular endothelial growth factor (VEGF) does not correlate with microvessel density in renal cell carcinoma. Neoplasma 2007, 54:278-284

90. Li Y, Wei Q, Feng J, Xu M, Huang R, Shi F: Expression of bone morphogenetic protein 2,4 , and related components of the BMP signaling pathway in the mouse uterus during the estrous cycle. J Zhejiang Univ Sci B 2014, 15:601-610.

91. Shi F, Stewart RL, Perez E, Chen JY-H, LaPolt PS: Cell-specific expression and regulation of soluble guanylyl cyclase alpha 1 and beta 1 subunits in the rat ovary. Biol Reprod 2004, 70:1552-1561.

92. Hawthorne AC, Xavier SP, Okamoto R, Salvador SL, Antunes AA, Salata LA: Immunohistochemical, tomographic, and histological study on onlay bone graft remodeling. part III: allografts. Clin Oral Implants Res 2013, 24:1164-1172.

93. Guskuma MH, Hochuli-Vieira E, Pereira FP, Rangel-Garcia I Jr, Okamoto R, Okamoto T, Filho OM: Evaluation of the presence of VEGF, BMP2 and CBFA1 proteins in autogenous bone graft: histometric and immunohistochemical analysis. J Cranio-Maxillofac Surg 2014, 42:333-339.

94. Yu YY, Lieu S, Lu C, Miclau T, Marcucio RS, Colnot C: Immunolocalization of BMPs, BMP antagonists, receptors, and effectors during fracture repair. Bone 2010, 46:841-851.

95. Li Y, Zhou X, Wei Q, Huang R, Shi F: Cell-specific expression and immunolocalization of nitric oxide synthase isoforms and soluble guanylyl cyclase $\alpha$ and $\beta$ subunits in postnatal porcine uteri. Acta Histochem 2014, 116:466-473.

96. Koerdt S, Siebers J, Bloch W, Ristow O, Kuebler AC, Reuther T: Role of oxidative and nitrosative stress in autogenous bone grafts to the mandible using guided bone regeneration and a deproteinized bovine bone material. J Cranio-Maxillo-fac Surg Off Publ Eur Assoc Cranio-Maxillo-fac Surg 2014, 42:560-567.

97. Ding W, Zhang W, Hui F, Zhang Y, Zhang F, Li X, Shi F: Cell-specific expression and immunolocalization of nitric oxide synthase isoforms and soluble guanylyl cyclase $\alpha 1$ and $\beta 1$ subunits in the ovary of fetal, neonatal and immature pigs. Anim Reprod Sci 2012, 131:172-180. 
98. Suter WN: Introduction to Educational Research: A Critical Thinking Approach. Second Edition edition. Thousand Oaks, Calif: SAGE Publications, Inc; 2011.

99. Shang ZJ, Li JR: Expression of endothelial nitric oxide synthase and vascular endothelial growth factor in oral squamous cell carcinoma: its correlation with angiogenesis and disease progression. J Oral Pathol Med Off Publ Int Assoc Oral Pathol Am Acad Oral Pathol 2005, 34:134-139.

100. Shackelford C, Long G, Wolf J, Okerberg C, Herbert R: Qualitative and quantitative analysis of nonneoplastic lesions in toxicology studies. Toxicol Pathol 2002, 30:93-96.

101. Thoolen B, Maronpot RR, Harada T, Nyska A, Rousseaux C, Nolte T, Malarkey DE, Kaufmann W, Küttler K, Deschl U, Nakae D, Gregson R, Vinlove MP, Brix AE, Singh B, Belpoggi F, Ward JM: Proliferative and nonproliferative lesions of the rat and mouse hepatobiliary system. Toxicol Pathol 2010, 38(7 Suppl):5S-81S.

102. De la Torre NG, Buley I, Wass JAH, Turner HE: Angiogenesis and lymphangiogenesis in thyroid proliferative lesions: relationship to type and tumour behaviour. Endocr Relat Cancer 2006, 13:931-944.

103. Jin Y, Tipoe GL, Liong EC, Lau TYH, Fung PCW, Leung KM: Overexpression of BMP-2/4, -5 and BMPR-IA associated with malignancy of oral epithelium. Oral Oncol 2001, 37:225-233.

104. Sappayatosok K, Maneerat Y, Swasdison S, Viriyavejakul P, Dhanuthai K, Zwang J, Chaisri U: Expression of pro-inflammatory protein, iNOS, VEGF and COX-2 in oral squamous cell carcinoma (OSCC), relationship with angiogenesis and their clinico-pathological correlation. Med Oral Patol Oral Cir Bucal 2009, 14:E319-E324.

105. Megumi K, Ishigami S, Uchikado Y, Kita Y, Okumura H, Matsumoto M, Uenosono Y, Arigami T, Kijima Y, Kitazono M, Shinchi H, Ueno S, Natsugoe S: Clinicopathological significance of BMP7 expression in esophageal squamous cell carcinoma. Ann Surg Oncol 2012, 19:2066-2071.

106. Hübner R-H, Gitter W, El Mokhtari NE, Mathiak M, Both M, Bolte $H_{\text {, }}$ Freitag-Wolf S, Bewig B: Standardized quantification of pulmonary fibrosis in histological samples. Biotechniques 2008, 44:507-511. 514-517.

107. Cheek E, Rajkumar C: How to present statistics in medical journals. Age Ageing 2014, 43:306-308

108. Klein M, Picard E, Vignaud JM, Marie B, Bresler L, Toussaint B, Weryha G, Duprez A, Leclère J: Vascular endothelial growth factor gene and protein: strong expression in thyroiditis and thyroid carcinoma. J Endocrinol 1999, 161:41-49.

109. Klein $M$, Vignaud JM, Hennequin $V$, Toussaint B, Bresler L, Plénat F, Leclère J, Duprez A, Weryha G: Increased expression of the vascular endothelial growth factor is a pejorative prognosis marker in papillary thyroid carcinoma. J Clin Endocrinol Metab 2001, 86:656-658.

110. Nakagawa S, Cuthill IC: Effect size, confidence interval and statistical significance: a practical guide for biologists. Biol Rev 2007, 82:591-605.

111. Remmele W, Stegner HE: Recommendation for uniform definition of an immunoreactive score (IRS) for immunohistochemical estrogen receptor detection (ER-ICA) in breast cancer tissue. Pathol 1987, 8:138-140.

112. McCarty KS, Miller LS, Cox EB, Konrath J, McCarty KS: Estrogen receptor analyses. correlation of biochemical and immunohistochemical methods using monoclonal antireceptor antibodies. Arch Pathol Lab Med 1985, 109:716-721.

113. Cagle PT, Sholl LM, Lindeman NI, Alsabeh R, Divaris DXG, Foulis P, Lee G, Neal JW, Nowak JA, Yu PP, Members of the Cancer Biomarker Reporting Workgroup, College of American Pathologists: Template for reporting results of biomarker testing of specimens from patients with non-small cell carcinoma of the lung. Arch Pathol Lab Med 2014, 138:171-174.

114. Bartley AN, Hamilton SR, Alsabeh R, Ambinder EP, Berman M, Collins E, Fitzgibbons PL, Gress DM, Nowak JA, Samowitz WS, Zafar SY, Members of the Cancer Biomarker Reporting Workgroup, College of American Pathologists: Template for reporting results of biomarker testing of specimens from patients with carcinoma of the colon and rectum. Arch Pathol Lab Med 2014, 138:166-170.

115. Allred DC, Harvey JM, Berardo M, Clark GM: Prognostic and predictive factors in breast cancer by immunohistochemical analysis. Mod Pathol Off J U S Can Acad Pathol Inc 1998, 11:155-168.

116. Harvey JM, Clark GM, Osborne CK, Allred DC: Estrogen receptor status by immunohistochemistry is superior to the ligand-binding assay for predicting response to adjuvant endocrine therapy in breast cancer. J Clin Oncol Off J Am Soc Clin Oncol 1999, 17:1474-1481.

117. Detre S, Saclani Jotti G, Dowsett M: A "quickscore" method for immunohistochemical semiquantitation: validation for oestrogen receptor in breast carcinomas. J Clin Pathol 1995, 48:876-878.
118. Sangplod P, Sangkhathat S, Boonpipattanapong T, Kanngurn S: Association of BMP6 methylation and expression with clinicopathological features in colorectal cancer. Int J Biosci Biochem Bioinforma 2013, 3(5):452-455.

119. Kejner $A E$, Burch MB, Sweeny $L$, Rosenthal EL: Bone morphogenetic protein 6 expression in oral cavity squamous cell cancer is associated with bone invasion. Laryngoscope 2013, 123:3061-3065.

120. Bramwell VH, Tuck AB, Chapman J-AW, Anborgh PH, Postenka CO, Al-Katib W, Shepherd LE, Han L, Wilson CF, Pritchard Kl, Pollak MN, Chambers AF: Assessment of osteopontin in early breast cancer: correlative study in a randomised clinical trial. Breast Cancer Res BC 2014, 16:R8.

121. Parris TZ, Aziz L, Kovacs A, Hajizadeh S, Nemes S, Semaan M, Chen CY, Karlsson P, Helou K: Clinical relevance of breast cancer-related genes as potential biomarkers for oral squamous cell carcinoma. BMC Cancer 2014, $14: 324$.

122. Koerdt S, Siebers J, Bloch W, Ristow O, Kuebler AC, Reuther T: Immunohistochemial study on the expression of von Willebrand factor (vWF) after onlay autogenous iliac grafts for lateral alveolar ridge augmentation. Head Face Med 2013, 9:40.

123. Koerdt S, Ristow O, Wannhoff A, Kübler AC, Reuther T: Expression of growth factors during the healing process of alveolar ridge augmentation procedures using autogenous bone grafts in combination with GTR and an anorganic bovine bone substitute: an immunohistochemical study in the sheep. Clin Oral Investig 2014, 18:179-188.

124. Raida M, Sarbia M, Clement JH, Adam S, Gabbert HE, Höffken K: Expression, regulation and clinical significance of bone morphogenetic protein 6 in esophageal squamous-cell carcinoma. Int J Cancer 1999, 83:38-44.

125. De Carvalho CHP, Nonaka CFW, de Araújo CRF, de Souza LB, Pinto LP: Immunoexpression of bone morphogenetic protein-2 (BMP-2), $\mathrm{BMP}$ receptor type $\mathrm{IA}$, and $\mathrm{BMP}$ receptor type II in metastatic and non-metastatic lower lip squamous cell carcinoma. J Oral Pathol Med Off Publ Int Assoc Oral Pathol Am Acad Oral Pathol 2011, 40:181-186.

126. Krajewska M, Krajewski S, Epstein Jl, Shabaik A, Sauvageot J, Song K, Kitada S, Reed JC: Immunohistochemical analysis of bcl-2, bax, bcl-X, and mcl-1 expression in prostate cancers. Am J Pathol 1996, 148:1567-1576.

127. Choudhury KR, Yagle KJ, Swanson PE, Krohn KA, Rajendran JG: A robust automated measure of average antibody staining in immunohistochemistry images. J Histochem Cytochem 2010, 58:95-107.

128. Fu D, Yang S, Li K, Yuan Y: Expression of vascular endothelial growth factor in bone morphogenic protein-2 induced osteogenesis. J Wuhan Univ Technol-Mater Sci Ed 2005, 20:118-122.

129. Zhu C, Wang J, Cheng T, Li Q, Shen H, Qin H, Cheng M, Zhang X: The potential role of increasing the release of mouse ?- defensin-14 in the treatment of osteomyelitis in mice: a primary study. PLoS One 2014, 9(1):e86874.

130. Zhang $H$, Zhao X, Zhang Z, Chen W, Zhang X: An Immunohistochemistry study of Sox9, Runx2, and osterix expression in the mandibular cartilages of newborn mouse. BioMed Res Int 2013, 2013:e265380.

131. Prichard J, Bitting A Myers J. Overview of Automated Immunohistochemistry. In Handb Pract Immunohistochem. Edited by Lin F, Prichard J. New York: Springer; 2011:23-30

132. Brey EM, Lalani Z, Johnston C, Wong M, McIntire LV, Duke PJ, Patrick CW: Automated selection of DAB-labeled tissue for immunohistochemical quantification. J Histochem Cytochem 2003, 51:575-584

133. Alvarenga AW, Coutinho-Camillo CM, Rodrigues BR, Rocha RM, Torres LFB, Martins VR, da Cunha IW, Hajj GNM: A comparison between manual and automated evaluations of tissue microarray patterns of protein expression. J Histochem Cytochem 2013, 61:272-282.

134. Schlederer M, Mueller KM, Haybaeck J, Heider S, Huttary N, Rosner M, Hengstschläger M, Moriggl R, Dolznig H, Kenner L: Reliable quantification of protein expression and cellular localization in histological sections. PLoS One 2014, 9:e100822.

135. Mohammed ZMA, Orange C, McMillan DC, Mallon E, Doughty JC, Edwards J, Going JJ: Comparison of visual and automated assessment of microvessel density and their impact on outcome in primary operable invasive ductal breast cancer. Hum Pathol 2013, 44:1688-1695.

136. Strömberg S, Björklund MG, Asplund C, Sköllermo A, Persson A, Wester K, Kampf C, Nilsson P, Andersson A-C, Uhlen M, Kononen J, Ponten F, Asplund $A$ : A high-throughput strategy for protein profiling in cell microarrays using automated image analysis. Proteomics 2007, 7:2142-2150. 
137. Kraan MC, Haringman JJ, Ahern MJ, Breedveld FC, Smith MD, Tak PP: Quantification of the cell infiltrate in synovial tissue by digital image analysis. Rheumatology 2000, 39:43-49.

138. Ali HR, Irwin M, Morris L, Dawson S-J, Blows FM, Provenzano E,

Mahler-Araujo B, Pharoah PD, Walton NA, Brenton JD, Caldas C:

Astronomical algorithms for automated analysis of tissue protein expression in breast cancer. Br J Cancer 2013, 108:602-612.

doi:10.1186/s13000-014-0221-9

Cite this article as: Fedchenko and Reifenrath: Different approaches for

interpretation and reporting of immunohistochemistry analysis results in the bone tissue - a review. Diagnostic Pathology 2014 9:221.

\section{Submit your next manuscript to BioMed Central and take full advantage of:}

- Convenient online submission

- Thorough peer review

- No space constraints or color figure charges

- Immediate publication on acceptance

- Inclusion in PubMed, CAS, Scopus and Google Scholar

- Research which is freely available for redistribution 